\title{
CATCH RATE FLUCTUATIONS OF SKIPJACK AND OTHER TUNA RESOURCES IN THE NORTHERN WATERS OF ACEH
}

\author{
Badrudin ${ }^{*}$ and Sofri Bahar ${ }^{*}$
}

\begin{abstract}
The most dominant species of the "large pelagic group" landed in Lampulo, Aceh, were skipjack, yellowfin tuna and small tuna. These fish were caught by mini purse seine through fishing activities carried out on a daily basis.

Data analysis was based on landings recorded at Lampulo Fishing Base, Banda Aceh. The data consisted of monthly catches and number of trips covering the 1985-1995 period.

Three distinct trends of catch and effort were observed within the period 1985-1995. During the period 1985-1987, the increase in effort was followed by an increase in both catch and catch per unit effort (CPUE). In the period 1987-1990 the decrease in effort was followed by a decrease in both catch and CPUE. From this phenomenon it likely that the surplus production model for the maximum sustainable yield estimation could not be applied. In the final period of 1990-1995, increase of effort resulted in an increase of catch but a slightly decreased CPUE.

Based on the average of the 11 years monthly catch rate within the period 1985-1995, it could be concluded that the best fishing season, as indicated by the higher catch rate, occurred early in the year from January-May.
\end{abstract}

KEYWORDS: tuna; skipjack; Aceh; Indonesia; CPUE.

\section{INTRODUCTION}

The "large pelagic resources" catagory of national fisheries statistics includes skipjack, other large tunas (yellowfin, bigeye), shark, small tuna and Spanish mackerel. As a result of their oceanic migratory behaviour the tuna resources available in the western Indonesian waters are believed to be a small portion of the Indian Ocean tuna population. This resource has been exploited and managed by several countries around the Indian Ocean from the east coast of Africa, the south coast and southeast coast of Asia, Mauritius, Seychelles, Maldive Islands and Australia under the Indo-Pacific Tuna Development and Management Programme (Ardill, 1994).
It is important for stock assessment purposes that data should be collected from the countries along their migratory path.

Various attempts have been made to assess these valuable resources. The potentials of skipjack and other large tuna resources in Indonesian waters were estimated to be 15,300 tonnes and 32,000 tonnes respectively (Uktolseja et al., 1991). However, according to Venema (1996) there has been a consensus among tuna specialists that at this stage of knowledge of these resources nobody can make reasonable predictions of the true potential. Historical trends from the eastern Indian Ocean suggest that the long line fishery for tuna is mature and large

\footnotetext{
Researcher of the Research Institute for Marine Fisheries, Jakarta
} 
increases in production cannot be expected. Eastern Indian Ocean skipjack, however, do not appear to be heavily exploited (Gillett, 1996).

The main Indonesian fishing bases for skipjack and other large tuna in the Indian Ocean are Sabang and Lampulo, Aceh; Bungus, West Sumatera; Pelabuhan Ratu. West Java; Prigi and Popoh, East Java; Benoa, Bali; and Kupang, Timor.

This study concentrates on the assessment of skipjack and other tuna resources based on the landing data from mini purse seine fisheries collected from the Lampulo Fishing Base, Banda Aceh. Quantities of sharks and Spanish mackerel as part of the large pelagic fish caught by purse seine in this area was very small, and therefore will not be included in the analysis. The term "large pelagic" in the following chapters refers only to the yellowfin tuna (Thunnus albacares), skipjack (Katsuwonus pelamis) and small tuna (Auxis spp., and Euthynnus spp.)

\section{MATERIALS AND METHODS}

Catch and effort data of the large pelagic: resources obtained from the Lampulo Fishing Base were collected in the form of daily landings, recorded from the small purse seine fisheries. These daily data were then tabulated and arranged into monthly and yearly bases. Catch data were recorded in tonnes, while effort data were in fishing days. Data for the period 1985-1990 from Bahar and Badrudin (1992) provide a combined record of skipjack, other large and small tuna, while the 1991-1995 data consisted separately of yellowfin tuna (Thunnus albacares), skipjack (Katsuwonus pelamis) and small tuna (Auxis spp., Euthynnus spp.). From this compilation the catch per unit effort (CPUE) in "catch per day" (one day fishing trip) between 1985-1995 was calculated as an index of abundance (Gulland, 1983). The exploitation status of the large pelagic resources in the area was expressed as the trend of CPUE.

\section{RESULTS AND DISCUSSIONS \\ Catch, Effort and Catch Per Unit Ef- fort (CPUE)}

From the annual catch and effort data of the skipjack resource in the northern waters of Aceh during the 1985-1995 period, three different patterns of trend were observed (Figure 1). During the 1985-1987 period an increase in effort was followed by a sharp increase in total catch, i.e., from 1876 tonnes in 1985 to 4890 tonnes in 1987 (Table 1). These increases were also followed by the increase in CPUE. On the other hand during the 1987-1990 period, the declining trend of effort was followed by the declining trend of both catch and CPUE. This situation is contrary to the classical surplus production model, where decreasing effort will usually be followed by increasing CPUE or the increase in effort will cause the decrease in CPUE (Sparre and Venema, 1992). From this it is apparent that the surplus production model leading to the estimation of the maximum sustainable yield (MSY) of this resource should not be applied as the result of its applications will be misleading.

During the 1990-1995 period, the trend of catch, effort and CPUE followed a classical theory of surplus yield models where the increase in effort was followed by an increase in catch butan overall decline in CPUE

\section{Monthly Catch Rates}

Based on the average monthly catch rate data for eleven years covering the 1985-1995 period, the lowest catch rate of $633 \mathrm{~kg} /$ day/ boat occurred in November while the highest catch rate of $913 \mathrm{~kg} /$ day/boat occurred in February (Table 2).

Fluctuations of monthly catch rates reflect the availability of fish in the sea and may be used as an indicator for abundance prediction of peak fishing season to optimize catches. Relatively high catch rates occurred in the 




- Catch (tonnes) - Effort (days)

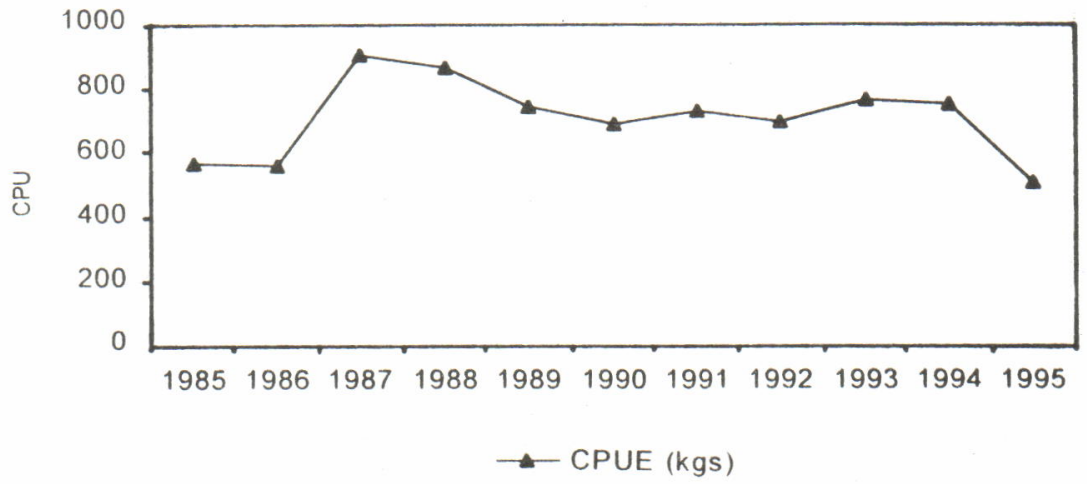

Figure. 1. Trends of catch, effort and CPUE of the merged tuna, skipjack and small tunas resources in the northern waers of Aceh, 1985-1995 (Lampulo Fishing Base)

early year around January, February, April and May with rates of ; 827, 913, 832 and 818 $\mathrm{kg} /$ day/boat. Catch rates during the rest of the year were between $600-700 \mathrm{~kg} /$ day/boat (Table 2, Figure 2). However, based on the observed lower and upper limits of the standard deviations of the average monthly catch rates which are overlapping, it is likely that the monthly catch rate fluctuation within this period was not statistically significant.

Catch rate fluctuations could also be used to analyze inter-specific interactions occurring in a resource community. The most common interaction in a dynamic community can be found in the form of a predator-prey relationship and/or food competition (Larkin et al., 1984). Based on tabulated 1991-1995 catch rate data it is apparent that an inter- specific interaction occurred between skipjack and small tunas. This is shown by the high catch rates of skipjack being mirrored by the low catch rate of small tunas and vice versa (Figure 3). The catch rate of larger tuna is similar to the pattern of the catch rate of skipjack. Interaction between species are complex. Yesaki (1994) reported that juvenile kawakawa (Euthynnus affinis) were found in the stomachs of skipjack and yellowfin. Roger (1994) suggested that surface tuna in the poor feeding areas form small schools swimming rapidly in search of richer areas, and feed on what they meet. In richer areas they form large schools feeding heavily on concentrations of prey fish, such as anchovies (Roger, 1994). What kind of interaction occurred between skipjack and small tuna in this area is still unknown. 


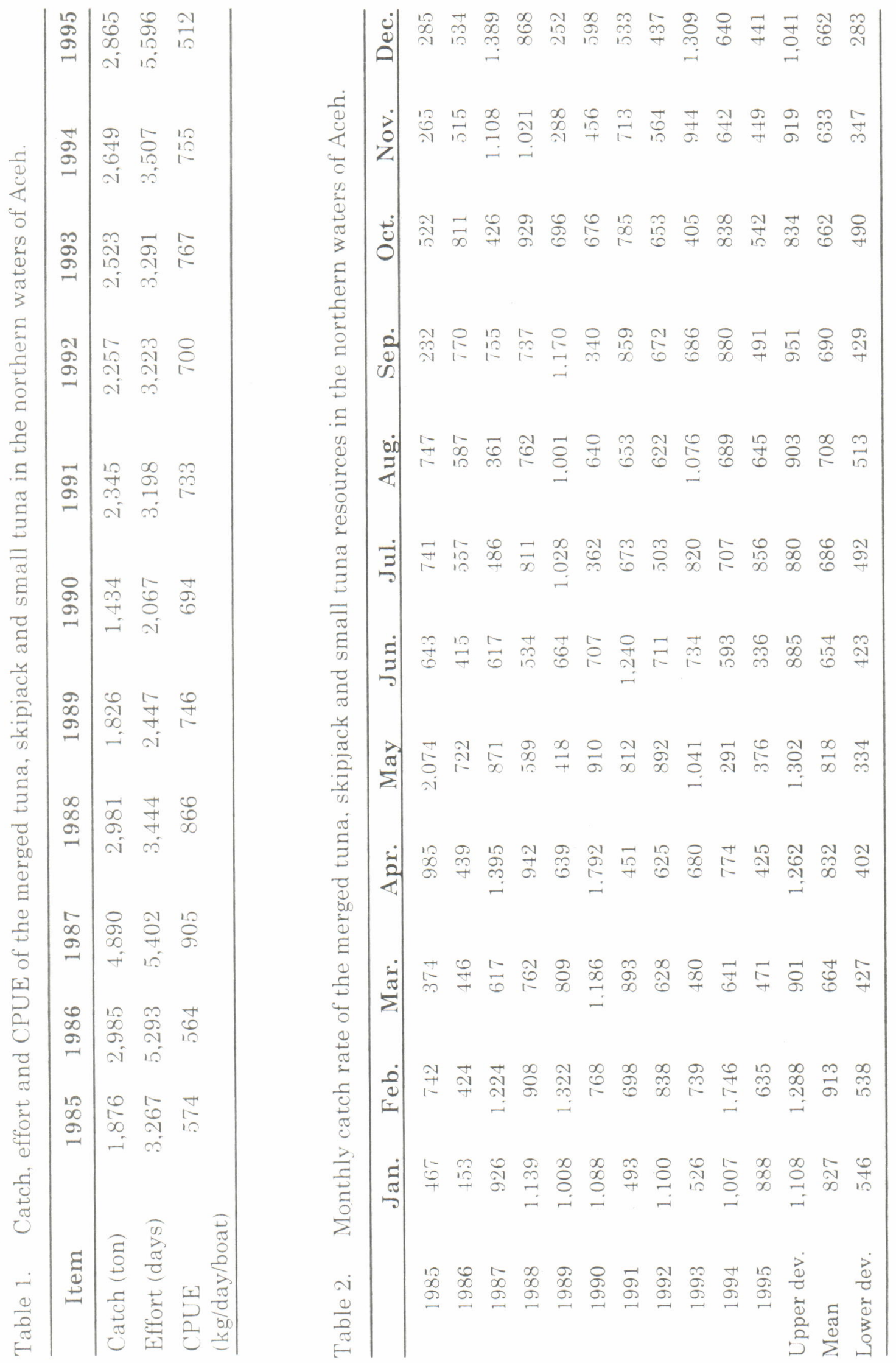






Figure 2. Average monthly catch rates of the merged tuna, skipjack and small tunas resources of the 1985-1995 period (Means + SD)

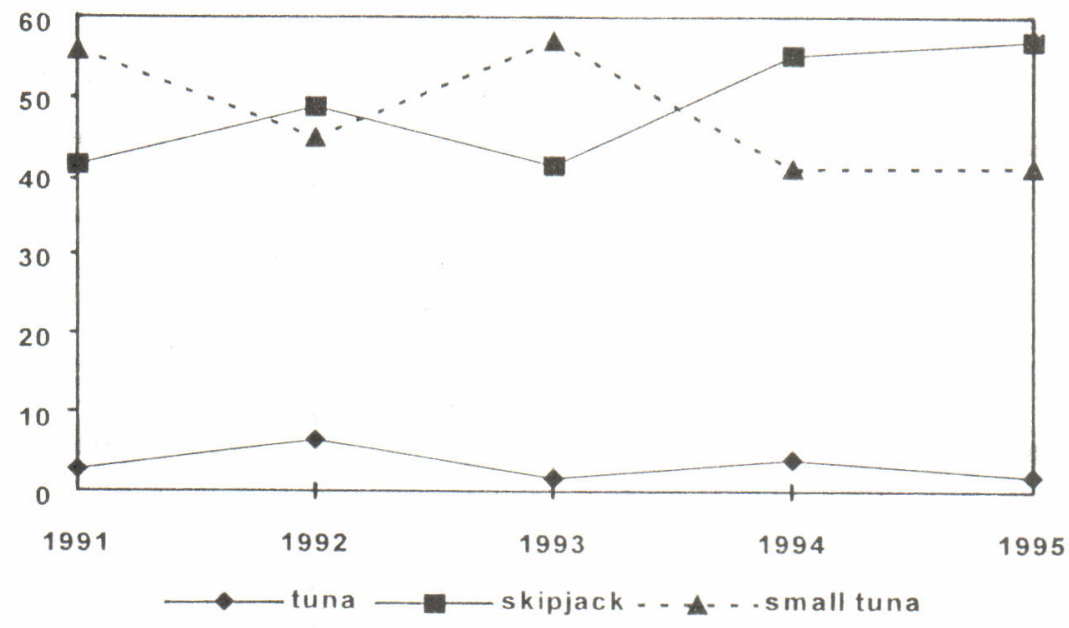

Figure 3. Annual trends of catch rates of tuna, skipjack and small tunas (in \% of the total large pelagic fish landings at Lampulo, Aceh)

\section{Catch Composition}

Most of the large pelagic fish catch landed at Lampulo Fishing Base were skipjack, other large tuna, and small tunas. The mean percentage of skipjack in this group was $49 \%$, small tunas contributed $48 \%$, and other large tuna made up the remaining $3 \%$ of the combined total catch (Table 3)

During the 1991-1995 period the percentage of skipjack in the small purse seine catches and other large tuna ranged between 41.2 and $57.1 \%$, and between 1.9 and $4.0 \%$, and small tuna between 40.8 and $57.1 \%$. 
Table 3. Percentage catch rate of skipjack, large tuna and small tunas 1991-1995.

\begin{tabular}{lrrrrrr}
\hline \multicolumn{1}{c}{ Year } & $\mathbf{1 9 9 1}$ & $\mathbf{1 9 9 2}$ & $\mathbf{1 9 9 3}$ & $\mathbf{1 9 9 4}$ & $\mathbf{1 9 9 5}$ & Average \\
\hline Skipjack & 41.3 & 48.7 & 41.2 & 55.2 & 57.1 & 48.70 \\
Large tuna & 2.8 & 6.5 & 1.7 & 4.0 & 1.9 & 3.38 \\
Small tunas & 55.9 & 44.8 & 57.1 & 40.8 & 41.0 & 47.92 \\
\hline
\end{tabular}

\section{Status of Exploitation}

The large pelagic fish populations landed at Lampulo are believed to be part of the Indian Ocean stock. Assessment of the stock to obtain a comprehensive ficture of the resource should incorporate data from neighbouring countries along the fishes' migratory path.

The trend of annual catch rates between the period 1985-1995 was almost flat with a slight decrease in 1995 . This was probably due to the high exploitation level in 1995 which produced a low catch rate of only 512 $\mathrm{kg} /$ day/ boat within that period. This implies that the level of exploitation of skipjack, other large tuna and small tuna resources in the northern waters of Aceh has probably reached full exploitation. Additional effort in terms of an increasing number of fishing boat is therefore not recommended. As fishing operations are now concentrated very close inshore, moves to cover more offshore waters need to be encouraged.

\section{CONCLUSIONS}

From the results and discussions, several conclusions may be drawn :

(1) Trend of catch rates of skipjack, other large tuna and small tuna resources showed a slight decrease during the 1985-1995 period, duly after 1987.
(2) Within that period, relatively high monthly catch rates occurred in the early period of the year, covering January, February, April and May.

(3) The average percentage catch rates of the total landings during 1991-1995 were skipjack $49 \%$, small tuna of $48 \%$, and other large tuna $3 \%$.

(4) Fishermen need to be encouraged to fish in more offshore waters and use longer fishing times to increase their yields.

\section{Acknowledgements}

The authors wish to express their gratitude to Mr. Zaharuddin, the RIMF enumerator at Lampulo Fishing Base for his assistances in the collection of fisheries data and information on fisheries activities. Thanks are also due to Mr. Safri Dahlan, the former Head of Lampulo Fishing Base and his successor, Mr. Dayur, for their help in providing data to complement this paper.

\section{REFERENCES}

Ardill, J.I) 1994 (Ed). Proceeding of the Expert Consultation on Indian Ocean Tunas. 5th. Session. Mahe, Seychelles, 4-8 October 1993. $275 \mathrm{p}$.

Bahar, S. and Badrudin. 1992. Tingkat pemanfaatan sumber daya ikan pelagis besar di perairan pantai utara Daerah Istimewa Aceh. Jur. Pen.Perik. Laut. No. 65: 41-48. 
Gillett, R.D. 1996. Marine Fishery Resources and Management in Indonesia with emphasis on the Extended Economic Zone. Workshop on Strengthening Marine Fisheries Development in Indonesia. TCP/INS/4553A. Jakarta, 23 April 1996. Directorate General of Fisheries FAO/UN. 35 p.

Gulland, J.A. 1983. Fish stock assessment: a manual of basic methods. FA()/Wiley Interscience. Vol.1. 223p.

Larkin, P.A., C.W.Clark, N.Daan, S.Dutt, V.Hongskul, S.A.Levin, G.G.Newman. D.M.Pauly, G.Radach and H.K.Rosenthal. 1984. Strategies for Multispecies Management. Group Report. In R.M.May (Ed). Exploitation of Marine Communities. Report of the Dahlem Workshop on Exploitation of Marine Communities. Berlin 1984, April 1-6. Springer-Verlag. Berlin. pp.287-301

Roger, C., 1994. On feeding conditions for surface tuna (Yellowfin, Thumnus albacares, and skipjack, Katsuwonus pelamis) in the western Indian Ocean. In Ardill, J.D., 1994. Proceedings of the expert consultation on Indian Ocean Tunas. 5th Session. Mahe. Seychelles.48 October 1993: 131-135.
Sparre, P. and S.C.Venema. 1992. Introduction to tropical fish stock assessment. Part 1. Manual. FAO Fish. Tech. Paper 306/1. Rev. 1. FAO UN. $376 \mathrm{p}$.

Uktolseja, J.C.B., B.Gafa, S.Bahar and E.Mulyadi. 1991. Potensi dan Penyebaran Sumber Daya Ikan Tuna dan Cakalang. In P. Martosubroto, N.Naamin dan B.B.A. Malik (Hds). Potensi dan Penyebaran Sumberdaya Ikan di Perairan Indonesia. Direk-torat Jenderal Perikanan-Puslitbang Perikanan . Puslitbang Oseanologi LIPI. 105 p.

Venema, S.C. 1996. Report on the INDONESIA/FAO/ DANIDA Workshop on the Assessment of the Potential of the Marine Fishery Resources in Indonesia. Jakarta, 13-24 March 1995. FAO,UN. Rome.34 p.

Yesaki, M., 1994. A review of the biology and fisheries for long tail tuna (Thunnus tonggol) in the Indo Pacific Region. In Shomura, R.S., J.Majkowski and S.Langi (Eds). Interaction of Pacific Tuna Fisheries. FAO.Fish.Tech.Pap. $336 / 2: 388-408$. 